\title{
Perbandingan Keterkaitan Antar Sektor Ekonomi Kota Bandung Berdasarkan Dua Periode Tabel Input Output
}

\author{
TETI SOFIA YANTI, SITI SUNENDIARI \\ Program Studi Statistika Unisba \\ tetisofiayanti@gmail.com
}

\begin{abstract}
ABSTRAK
Pembangunan ekonomi suatu daerah memerlukan suatu perencanaan yang matang sehingga pembangunan dapat mencapai daya guna yang tinggi. Untuk keperluan perencanaan dan evaluasi hasil-hasil pembangunan yang bersifat menyeluruh baik skala nasional maupun skala yang lebih kecil (tingkat kabupaten/kota), model pendekatan perencanaan pembangunan wilayah dapat menggunakan model analisis input-output. Kota Bandung secara periodik mempublikasikan tabel input output. Tabel input output yang sudah dimiliki Kota Bandung adalah tahun 2003 dan tahun 2008. Terjadi perubahan sektor unggulan maupun sektor yang lemah di Kota Bandung. Rata-rata penyebaran maupun derajat kepekaan berubah dari 1,29 menjadi 1,77. Peningkatan terjadi terbesar ada pada sektor perdagangan, dimana perubahan daya penyebaran sebesar 1,31 dan pada derajat kepekaan sebesar 21,72. Nilai tersebut sangat besar sekali terutama pada derajat kepekaan, ini mengindikasikan perekonomian Kota Bandung sudah berubah dari Kota Jasa menjadi kota Perdagangan. Hal tersebut didukung oleh kontribusi perdangangan untuk PDRB tahun 2014 sebesar $27,79 \%$ sedangkan untuk sektor jasa sebesar $12,44 \%$.
\end{abstract}

Kata kunci: Daya penyebaran, derajat kepekaan, sektor unggulan, analisis input output, matriks teknologi

\section{PENDAHULUAN}

Pembangunan ekonomi suatu daerah memerlukan suatu perencanaan yang matang sehingga pembangunan dapat mencapai daya guna yang tinggi. Strategi dan kebijakan pembangunan ekonomi yang telah dilaksanakan pada masa-masa yang lalu perlu dievaluasi baik hasil maupun implikasinya. Berbagai data statistik yang merupakan ukuran kuantitas mutlak diperlukan untuk memberikan gambaran tentang keadaan masa lalu, masa kini serta sasaran-sasaran yang akan dicapai pada masa yang akan datang.

Proses pembangunan dilihat sebagai perubahan pada kegiatan dan tata susunan ekonomi masyarakat yang bersangkutan. Perubahan struktural suatu perekonomian menyangkut perubahan-perubahan pada struktur produk nasional dan komposisi produk nasional, kesempatan kerja, ketimpangan antar sektoral, antar daerah, dan antar golongan masyarakat. Transformasi struktural merupakan prasyarat dari peningkatan dan kesinambungan pertumbuhan serta penanggulangan kemiskinan, sekaligus pendukung bagi keberlanjutan pembangunan itu sendiri. Perubahan struktural mengindikasikan telah terjadi perubahan potensi ekonomi suatu daerah atau negara.

Menentukan potensi daerah/negara sangat diperlukan, karena dapat mengetahui kekuatan, kelemahan, peluang dan ancaman daerah atau negara tersebut. Ketika empat elemen diatas dapat dipetakan dengan baik dan benar maka hal ini akan memberikan dampak yang positif terhadap ketersediaan informasi sebagai bahan dasar perumusan suatu kebijakan pemerintah dalam menjalankan fungsi melayani, membangun, memberdayakan masyarakat, serta membuat peraturan sebagai langkah awal dalam mengantisipasi dampak buruk perekonomian global (Rasyid, 1997).

Berdasarkan Peraturan Daerah Kota Bandung Nomor 09 Tahun 2009 tentang RPJMD Kota Bandung Tahun 2009-2013, Visi Kota Bandung adalah :"Memantapkan Kota Bandung sebagai Kota Jasa Bermartabat”. Kota Bermartabat diartikan sebagai kota yang mempunyai jati diri, harga diri dan kebanggaan bagi seluruh warganya, memiliki pelayanan publik prima 
tanpa membedakan status. Arah visi tersebut adalah memerankan Kota Bandung sebagai kota jasa.

Untuk keperluan perencanaan dan evaluasi hasil-hasil pembangunan yang bersifat menyeluruh baik skala nasional maupun skala yang lebih kecil (tingkat kabupaten/kota), model pendekatan perencanaan pembangunan wilayah dapat menggunakan model analisis input-output. Kota Bandung secara periodik mempublikasikan tabel input output. Tabel input output yang sudah dimiliki Kota Bandung adalah tahun 2003 dan tahun 2008. Berdasakan kedua tabel tersebut akan dilakukan analisis perbandingan keterkaitan antar sektor melalui analisis input output.

\section{ANALISIS INPUT OUTPUT}

Untuk keperluan perencanaan dan evaluasi hasil-hasil pembangunan yang bersifat menyeluruh baik skala nasional maupun skala yang lebih kecil (tingkat kabupaten/kota), model pendekatan perencanaan pembangunan wilayah dapat menggunakan model analisis input-output. Melalui model analisis input output dapat dilihat keterkaitan antar sektor dalam perekonomian sehingga dapat diketahui kinerja suatu sektor dalam perekonomian dan langkah kebijakan perekonomian yang tepat dalam pembangunan (Amir 2005).

\subsection{Matriks Koefisien Input (Matriks Teknologi)}

Misalkan perekonomian terdiri dari dua sektor ekonomi, memiliki variabel-variabel input antara $(\mathrm{Z})$, output $(\mathrm{X})$, permintaan akhir $(\mathrm{Y})$ dan variabel input primer $(\mathrm{W})$. Keempat variabel tersebut jika diuraikan dalam bentuk matriks sebagai berikut:

$$
Z=\left(\begin{array}{ll}
z_{11} & z_{12} \\
z_{21} & z_{22}
\end{array}\right), \mathbf{X}=\left(\begin{array}{l}
X_{1} \\
X_{2}
\end{array}\right), \mathbf{Y}=\left(\begin{array}{c}
C_{1}+G_{1}+I_{1}+E_{1} \\
C_{2}+G_{2}+I_{2}+E_{2}
\end{array}\right)=\left(\begin{array}{l}
Y_{1} \\
Y_{2}
\end{array}\right), W=\left(\begin{array}{cc}
L_{1} & L_{2} \\
N_{1} & N_{2}
\end{array}\right)
$$

dengan:

$\mathrm{C}=$ konsumsi rumah tangga, $\mathrm{G}=$ belanja pemerintah, $\mathrm{I}=$ investasi

$\mathrm{E}=$ ekspor, $\mathrm{L}=$ tenaga kerja, $\mathrm{N}=$ nilai tambah

Hubungan antara $\mathrm{Z}$ dan $\mathrm{X}$ menyatakan koefisien teknologi atau koefisien input-output yaitu:

$$
a_{i j}=\frac{z_{i j}}{X_{j}}
$$

Jika terdapat $\mathrm{n}$ sektor di dalam perekonomian, maka akan terdapat ( $\mathrm{x} \mathrm{x}$ ) koefisien teknologi yang disebut matriks teknologi (A).

\subsection{Matriks Pengganda}

Matriks pengganda (I-A)-1 digunakan untuk melakukan analisis dampak atau multiplier effect. Matriks pengganda atau matriks kebalikan Leontif dirumuskan sebagai berikut:

$$
(\mathrm{I}-\mathrm{A})^{-1}=\left(\left(\begin{array}{cccc}
1 & 0 & \cdots & 0 \\
1 & 1 & \cdots & 0 \\
\vdots & \vdots & \ddots & \vdots \\
0 & 0 & \cdots & 1
\end{array}\right)-\left(\begin{array}{cccc}
a_{11} & a_{12} & \cdots & a_{1 n} \\
a_{21} & a_{22} & \cdots & a_{2 n} \\
\vdots & \vdots & \ddots & \vdots \\
a_{n 1} & a_{n 2} & \cdots & a_{n n}
\end{array}\right)\right)^{-1}=\left(\begin{array}{cccc}
b_{11} & b_{12} & \cdots & b_{1 n} \\
b_{21} & b_{22} & \cdots & b_{2 n} \\
\vdots & \vdots & \ddots & \vdots \\
b_{n 1} & b_{n 2} & \cdots & b_{n n}
\end{array}\right)
$$

\subsection{Analisis Keterkaitan Antar Sektor (Linkages)}

Pada tabel input output hubungan antara output dan permintaan akhir dijabarkan sebagai :

$$
\mathrm{X}=(\mathrm{I}-\mathrm{A})^{-1} \mathbf{Y}
$$


Secara umum jumlah dampak akibat perubahan permintaan akhir suatu sektor terhadap output seluruh sektor ekonomi adalah:

$$
r_{j}=b_{1 j}+b_{2 j}+\ldots+b_{n j}=\sum b_{i j}
$$

Jumlah dampak akibat perubahan permintaan akhir suatu sektor terhadap output seluruh sektor ekonomi dapat memperlihatkan keterkaitan kebelakang (backward linkage) dan keterkaitan kedepan (forward linkage). Dalam hubungannya untuk setiap sektor ekonomi dapat dijelaskan melalui indeks daya penyebaran $(\alpha)$ dan indeks derajat kepekaan ( $\beta$ ) dirumuskan sebagai berikut:

$$
\alpha_{j}=\frac{\sum_{i=1}^{n} b_{i j}}{(1 / n) \sum_{i} \sum_{j} b_{i}}, \quad \beta_{i}=\frac{\sum_{j=1}^{n} b_{i j}}{(1 / n) \sum_{i} \sum_{j} b_{i}}
$$

dengan :

$$
\begin{array}{ll}
\alpha_{\mathrm{j}} & =\text { indeks daya penyebaran sektor } \mathrm{j} \\
\beta_{\mathrm{i}} & =\text { indeks derajat kepekaan sektor } \mathrm{i} \\
\sum_{i=1}^{n} b_{i j} & =\text { jumlah daya penyebaran sektor } \mathrm{j} \\
\sum_{j=1}^{n} b_{i j} & =\text { jumlah derajat kepekaan sektor } \mathrm{i}
\end{array}
$$

Hubungan antara indeks daya penyebaran $(\alpha)$ dan indeks derajat kepekaan ( $\beta$ ) dapat digambarkan pada Gambar 1.

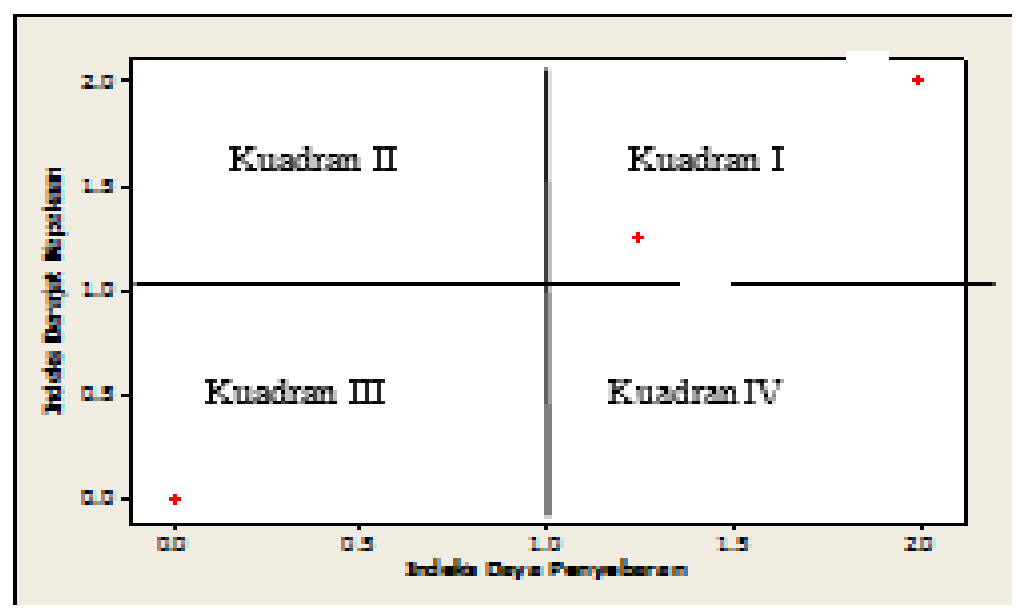

Gambar 1. Plot nilai a dan $\beta$

Gambar di atas dibagi menjadi empat kuadran, yaitu :

1. Kuadran I, menunjukkan bahwa sektor ini dianggap sebagai "leader" dalam pertumbuhan ekonomi.

2. Kuadran II, menunjukkan ketegantungan sektor ini terhadap sektor lain tinggi, sedangkan daya dorong terhadap sektor lain kecil.

3. Kuadran III, menunjukkan sektor ini memerlukan dorongan dan dukungan dari sektor lain karena kemampuan diri sektor ini lemah.

4. Kuadran IV, menunjukkan dapat mendorong sektor lain, tetapi tingkat ketergantungannya terhadap sektor lain rendah. 


\section{HASIL DAN PEMBAHASAN}

Data yang dianalisis adalah tabel input output Kota Bandung tahun 2003 dan tahun 2008. Tabel input output tahun 2003 memuat 53 sektor ekonomi, sedangkan untuk tahun 2008 memuat 54 sektor ekonomi, akan tetapi jenis sektor di dua periode tersebut berbeda. Analisis perbandingan memerlukan jenis sektor yang yang sama, sehingga terdapat beberapa sektor yang digabungkan sehingga terdapat 46 sektor ekonomi yang akan dibandingkan. Berikut nama-nama sektor yang akan dibandingkan pada periode survey.

Tabel 1. Nama-nama Sektor Ekonomi

\begin{tabular}{|c|c|c|c|}
\hline Kode & Sektor & Kode & Sektor \\
\hline 1 & Tanaman Bahan Makanan & 24 & Industri Pengolahan Lainnya \\
\hline 2 & Ternak, Unggas, dan Hasil-Hasilnya & 25 & Listrik \\
\hline 3 & Perikanan dan Hasil Perikanan Lainnya & 26 & Air Bersih \\
\hline 4 & Hasil Pertanian Lainnya & 27 & Konstruksi \\
\hline 5 & $\begin{array}{l}\text { Barang Tambang dan Hasil Galian } \\
\text { Lainnya }\end{array}$ & 28 & Perdagangan \\
\hline 6 & Industri makanan & 29 & Perhotelan \\
\hline 7 & $\begin{array}{l}\text { Industri Tekstil kecuali untuk Pakaian } \\
\text { Jadi }\end{array}$ & 30 & Restoran \\
\hline 8 & Industri Perajutan & 31 & Jasa Angkutan Kereta Api \\
\hline 9 & $\begin{array}{l}\text { Industri Pakaian Jadi kecuali untuk Alas } \\
\text { Kaki }\end{array}$ & 32 & Jasaa Angkutan Jalan \\
\hline 10 & $\begin{array}{l}\text { Industri Kulit, Barang-Barang dari Kulit, } \\
\text { dan Alas Kaki } \\
\text { Kayu dan Barang-Barang Lainnya }\end{array}$ & 33 & Jasa Angkutan Udara \\
\hline 11 & $\begin{array}{l}\text { Terbuat dari Kayu, Gabus,Bambu, dan } \\
\text { Rotan }\end{array}$ & 34 & Jasa Penunjang Angkutan \\
\hline 12 & Industri Furnitur Semua Bahan & 35 & Jasa Komunikasi \\
\hline 13 & $\begin{array}{l}\text { Industri Kertas, Barang dari Kertas, dan } \\
\text { Sejenisnya }\end{array}$ & 36 & $\begin{array}{l}\text { Bank dan laembaga keuangan } \\
\text { lainnya }\end{array}$ \\
\hline 14 & Industri Penerbitan dan Percetakan & 37 & Jasa Perusahaan \\
\hline 15 & Industri Penghangan Minyak Bumi & 38 & $\begin{array}{l}\text { Real Estate dan Usaha } \\
\text { Persewaan }\end{array}$ \\
\hline 16 & $\begin{array}{l}\text { Industri Kimia dan Barang-Barang dari } \\
\text { Kimia }\end{array}$ & 39 & Jasa Pemerintahan Umum \\
\hline 17 & $\begin{array}{l}\text { Industri Minyak dan Barang-Barang dari } \\
\text { Karet }\end{array}$ & 40 & Jasa Pendidikan Pemerintah \\
\hline 18 & $\begin{array}{l}\text { Industri Barang-Barang dari Plastik } \\
\text { kecuali Furniture }\end{array}$ & 41 & Jasa Kesehatan Pemerintah \\
\hline 19 & Industri Barang Galian bukan Logam & 42 & Jasa Pendidikan Swasta \\
\hline 20 & $\begin{array}{l}\text { Industri Logam Dasar dan Barang dari } \\
\text { Logam, kecuali }\end{array}$ & 43 & Jasa Kesehatan Swasta \\
\hline 21 & $\begin{array}{l}\text { Industri Mesin dan Peralatannya } \\
\text { termasuk Perlengkapannya }\end{array}$ & 44 & $\begin{array}{l}\text { Jasa Sosial Kemasyarakatan } \\
\text { Swasta Lainya }\end{array}$ \\
\hline 22 & Industri Alat Angkutan & 45 & $\begin{array}{l}\text { Jasa Rekreasi Kebudayaan dan } \\
\text { Olah Raga }\end{array}$ \\
\hline 23 & $\begin{array}{l}\text { Peralatan Profesional, Ilmu Pengetahuan, } \\
\text { Alat Ukur, dan Pengatur }\end{array}$ & 46 & $\begin{array}{l}\text { Jasa Perorangan dan Rumah } \\
\text { Tangga, dan jasa lainya }\end{array}$ \\
\hline
\end{tabular}

Adapun perbandingan daya penyebaran dan derajat kepekaan, yang digunakan untuk melihat keterkaitan antar sektor terdapat pada Tabel 2, dan Gambar 2 dan 3. 
Tabel 2. Daya Penyebaran dan Derajat Kepekaan Kota Bandung Tahun 2003 dan 2008

\begin{tabular}{|c|c|c|c|c|c|c|c|c|c|}
\hline \multirow{2}{*}{$\begin{array}{l}\text { KOD } \\
\mathbf{E}\end{array}$} & \multicolumn{2}{|c|}{$\begin{array}{c}\text { Daya } \\
\text { Penyebaran }\end{array}$} & \multicolumn{2}{|c|}{$\begin{array}{c}\text { Derajat } \\
\text { Kepekaan }\end{array}$} & \multirow{2}{*}{$\begin{array}{c}\text { KOD } \\
\mathbf{E}\end{array}$} & \multicolumn{2}{|c|}{$\begin{array}{c}\text { Daya } \\
\text { Penyebaran }\end{array}$} & \multicolumn{2}{|c|}{$\begin{array}{c}\text { Derajat } \\
\text { Kepekaan }\end{array}$} \\
\hline & 2003 & 2010 & 2003 & 2010 & & 2003 & 2010 & 2003 & 2010 \\
\hline 1 & 1,00 & 1,13 & 1,11 & 1,01 & 24 & 1,05 & 1,90 & 1,23 & 1,00 \\
\hline 2 & 1,05 & 1,25 & 1,03 & 1,02 & 25 & 1,78 & 2,31 & 1,47 & 1,98 \\
\hline 3 & 1,03 & 1,11 & 1,05 & 1,06 & 26 & 1,31 & 1,31 & 1,07 & 1,50 \\
\hline 4 & 1,00 & 1,00 & 1,01 & 1,07 & 27 & 1,56 & 2,65 & 1,33 & 1,38 \\
\hline 5 & 1,00 & 1,00 & 1,05 & 1,06 & 28 & 1,35 & 2,66 & 1,83 & 23,55 \\
\hline 6 & 1,17 & 1,43 & 1,11 & 1,07 & 29 & 1,90 & 2,28 & 1,62 & 1,05 \\
\hline 7 & 1,69 & 1,58 & 1,60 & 1,02 & 30 & 1,13 & 2,14 & 1,16 & 1,37 \\
\hline 8 & 1,54 & 2,19 & 1,26 & 1,00 & 31 & 1,34 & 1,57 & 1,10 & 1,29 \\
\hline 9 & 1,69 & 2,10 & 1,11 & 1,01 & 32 & 1,30 & 2,69 & 1,21 & 2,78 \\
\hline 10 & 1,58 & 2,57 & 1,36 & 1,15 & 33 & 1,50 & 2,91 & 1,35 & 2,37 \\
\hline 11 & 1,20 & 1,77 & 1,14 & 1,03 & 34 & 1,64 & 1,89 & 1,30 & 1,18 \\
\hline 12 & 1,05 & 1,15 & 1,02 & 1,03 & 35 & 1,95 & 1,31 & 2,05 & 1,84 \\
\hline 13 & 1,03 & 1,03 & 1,14 & 1,07 & 36 & 1,67 & 1,44 & 2,03 & 1,54 \\
\hline 14 & 1,28 & 1,72 & 1,07 & 1,07 & 37 & 1,12 & 2,29 & 1,69 & 1,30 \\
\hline 15 & 1,00 & 1,00 & 1,70 & 1,06 & 38 & 1,02 & 2,08 & 1,31 & 2,21 \\
\hline 16 & 1,29 & 1,34 & 2,01 & 1,03 & 39 & 1,60 & 1,16 & 1,07 & 1,25 \\
\hline 17 & 1,29 & 1,91 & 1,11 & 1,20 & 40 & 1,56 & 1,17 & 1,32 & 1,10 \\
\hline 18 & 1,06 & 1,91 & 1,11 & 1,44 & 41 & 1,13 & 2,26 & 1,26 & 1,15 \\
\hline 19 & 1,03 & 1,15 & 1,11 & 1,07 & 42 & 1,23 & 2,07 & 1,16 & 1,20 \\
\hline 20 & 1,23 & 1,00 & 1,30 & 1,00 & 43 & 1,30 & 2,13 & 1,26 & 1,11 \\
\hline 21 & 1,18 & 2,00 & 1,22 & 1,03 & 44 & 1,01 & 2,10 & 1,09 & 1,12 \\
\hline 22 & 1,23 & 1,42 & 1,26 & 1,02 & 45 & 1,07 & 2,15 & 1,05 & 1,22 \\
\hline 23 & 1,02 & 1,18 & 1,10 & 1,01 & 46 & 1,04 & 2,80 & 1,30 & 2,16 \\
\hline
\end{tabular}

Rata-rata daya penyebaran maupun derajat kepekaan sudah berubah dari tahun 2003 ke tahun 2008. Rata-rata daya penyebaran 1,29 artinya ketika permintaan akhir di seluruh sektor ekonomi berubah sebesar Rp.1 juta maka rata-rata setiap sektor ekonomi meningkat outputnya sebesar Rp 1,29 juta. Peningkatan daya penyebaran terjadi pada 36 sektor, dan perubahan tertinggi terjadi pada sektor 46. Selain peningkatan terdapat 8 sektor yang menurun, dan penurunan tertinggi terjadi pada sektor 35.

Rata-rata derajat kepekaan 1,29 artinya ketika permintaan akhir suatu sektor ekonomi berubah sebesar Rp.1 juta maka rata-rata seluruh sektor ekonomi meningkat outputnya sebesar Rp 1,29 juta. Peningkatan derajat kepekaan terjadi pada 21 sektor, dan perubahan tertinggi terjadi pada sektor 28. Selain peningkatan terdapat 25 sektor yang menurun, dan penurunan tertinggi terjadi pada sektor 16. 


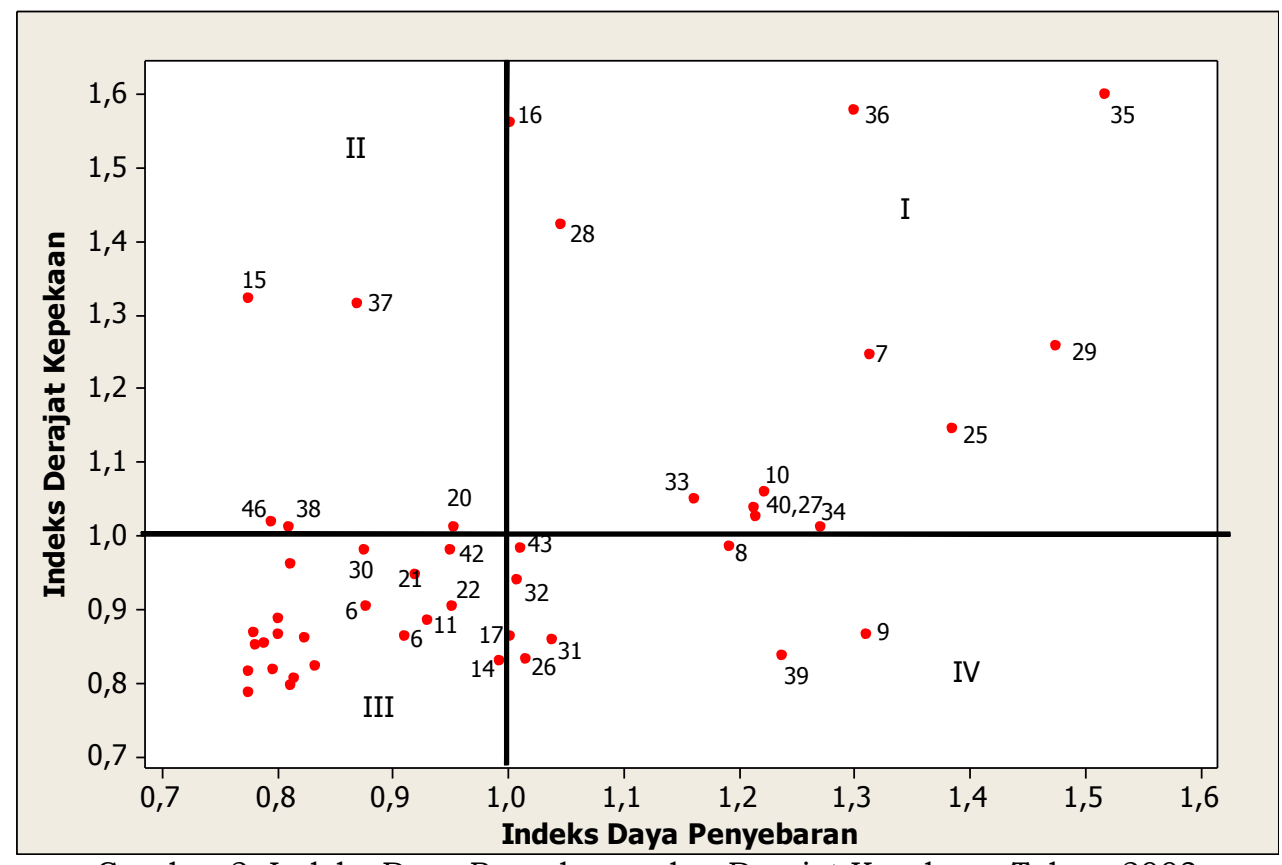

Gambar 2. Indeks Daya Penyebaran dan Derajat Kepekaan Tahun 2003

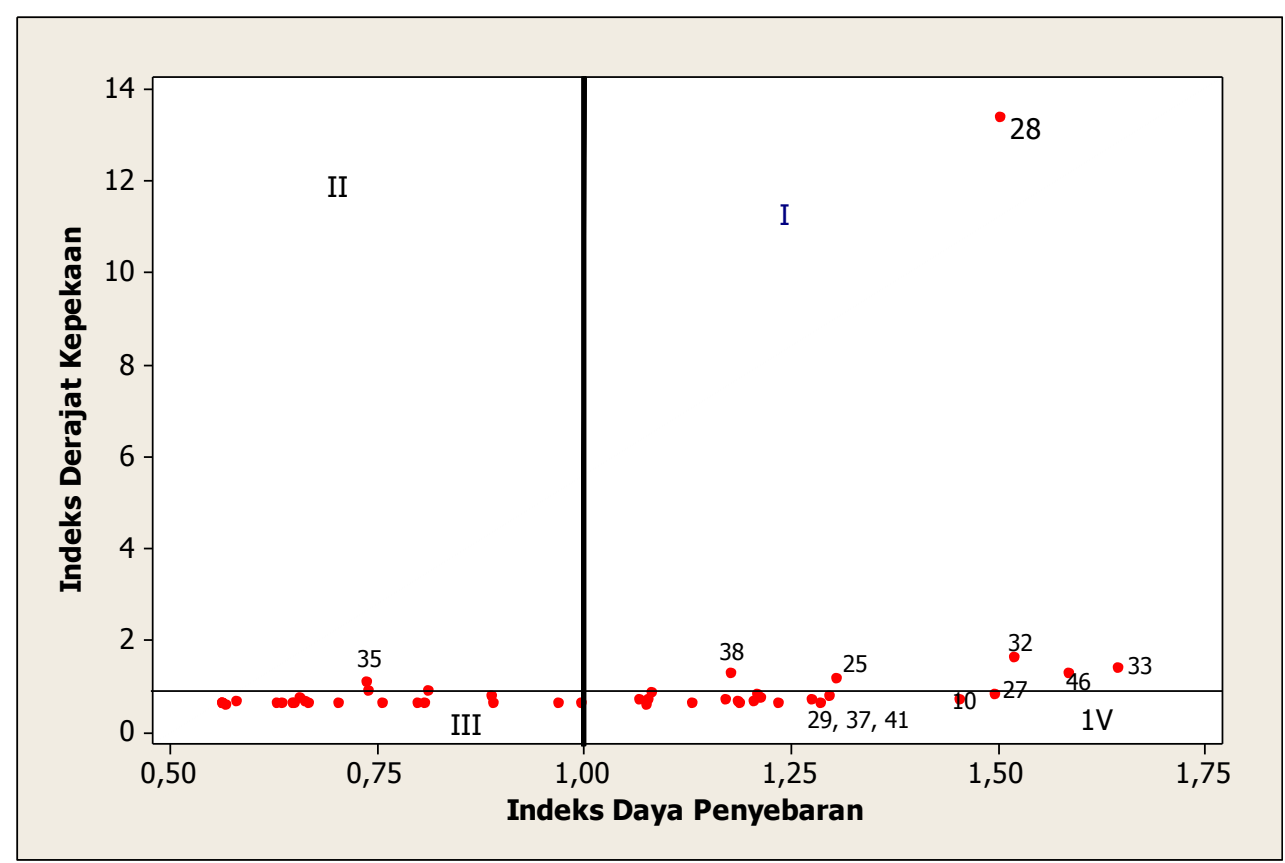

Gambar 3. Indeks Daya Penyebaran dan Derajat Kepekaan Tahun 2008

Dari Gambar 2 dan 3 terlihat berbeda dalam struktur pencaran data. Tahun 2003 dan 2008 terlihat indeks daya penyebaran nilainya relatif sama antara 0,5 sampai 1,6, akan tetapi untuk indeks derajat kepekaan terlihat jauh berbeda dimana tahun 2003 nilainya antara 0,79 sampai 1,60, sedangkan tahun 2008 nilainya antara 0,57 sampai 13,34. Berikut perubahan pencaran terdapat pada Tabel 3. 
Tabel 3. Perbandingan Kondisi Sektor Tahun 2003 dan 2008

\begin{tabular}{ccc}
\hline Kondisi & Tahun 2003 & Tahun 2008 \\
Kuadran I & 12 & 6 \\
Kuadran II & 5 & 1 \\
Kuadran III & 21 & 21 \\
Kuadran IV & 8 & 18 \\
Sektor Unggulan (kuadran I) & $7 ; 10 ; 16 ; 25 ; 27 ; 28 ;$ & $25 ; 28 ; 32 ; 33 ; 38 ; 46$ \\
& $29 ; 33 ; 34 ; 35 ; 36$ & $1 ; 2 ; 3 ; 4 ; 5 ; 6 ; 7 ; 12 ; 13 ;$ \\
Sektor Paling Lemah (Kuadran III) & $1 ; 2 ; 3 ; 4 ; 5 ; 6 ; 11 ; 12 ; 13 ;$ & $14 ; 15 ; 16 ; 19 ; 20 ; 22 ;$ \\
& $14 ; 18 ; 19 ; 21 ; 22 ; 23 ; 24 ;$ & $23 ; 26 ; 31 ; 36 ; 39 ; 40$ \\
Daya penyebaran terkecil & $30 ; 41 ; 42 ; 44 ; 45$ & $1,00$ (sektor 4,5, 15$)$ \\
Daya penyebaran terbesar & $1,00$ (sektor $1,5,15)$ & 2,91 (sektor 33) \\
Derajat kepekaan terkecil & 1,95 (sektor 35) & 1,00 (sektor 8, 20, 24) \\
Derajat kepekaan terbesar & 1,01 (sektor 4) & 23,55 (sektor 28) \\
\hline
\end{tabular}

Terlihat terjadi perubahan komposisi jumlah dan sektor pada kuadran I sampai Kuadran IV. Pada tahun 2008 sektor 7 (Industri Tekstil kecuali untuk Pakaian Jadi), 10(Industri Kulit, Barang-Barang dari Kulit, dan Alas Kaki), 16(Industri Kimia dan Barang-Barang dari Kimia), 27(Konstruksi), 29(Perhotelan), 34(jasa penunjang angkutan), dan 35(Jasa komunikasi) sudah tidak menjadi sektor unggulan. Sektor unggulan pada tahun 2005 adalah 25(listrik), 28(Perdagangan), 32(Jasa angkutan jalan), 33(Jasa angkutan udara), 38(real estate dan usaha persewaan), 46(Jasa Perseorangan, rumah tangga dan jasa lainnya).

Daya penyebaran terbesar berubah dari sektor 35(jasa komunikasi) menjadi sektor 32(Jasa angkutan jalan). Untuk sektor Jasa Angkutan ketika permintaan akhir di sektor tersebut meningkat sebesar Rp 1 juta maka mampu meningkatkan output seluruh sektor sebesar Rp 2,91 juta. Derajat kepekaan terbesar berubah dari sektor 35(jasa komunikasi) menjadi sektor 28(perdagangan). Untuk sektor perdagangan ketika permintaan akhir diseluruh sektor meningkat sebesar Rp 1 juta maka sektor perdagangan akan meningkat sebesar RP 23,55 juta, sedangkan daya penyebaran sektor tersebut sebesar 2,66. Khusus untuk sektor perdagangan perubahan terjadi pada daya penyebaran sebesar 1,31 dan pada derajat kepekaan sebesar 21,72 .

\section{KESIMPULAN}

Terjadi perubahan sektor unggulan maupun sektor yang lemah di Kota Bandung. Rata-rata penyebaran maupun derajat kepekaan berubah dari 1,29 menjadi 1,77. Peningkatan terjadi terbesar ada pada sektor perdagangan, dimana perubahan daya penyebaran sebesar 1,31 dan pada derajat kepekaan sebesar 21,72. Nilai tersebut sangat besar sekali terutama pada derajat kepekaan, ini mengindikasikan perekonomian Kota Bandung sudah berubah dari Kota Jasa menjadi kota Perdangangan. Hal tersebut didukung oleh kontribusi perdangangan untuk PDRB tahun 2014 sebesar 27,79\% sedangkan untuk sektor jasa sebesar 12,44\%.

\section{UCAPAN TERIMA KASIH}

Penelitian ini merupakan bagian dari penelitian hibah bersaing yang didanai oleh Dikti tahun anggaran 2016, dengan nomor kontrak Nomor:238/LPPM-SP3/V/2016 tentang Surat Perjanjian Pelaksanaan Penelitian(SP3) Hibah Bersaing.

\section{DAFTAR PUSTAKA}

Amir, Hidayat, dkk. (2005). Jurnal Keuangan Dan Moneter. Analisis Sektor Unggulan Untuk Evaluasi Kebijakan Pembangunan Jawa Timur Menggunakan Tabel Input-Output 1994 Dan 2000. Departemen Keuangan RI . Edisi Desember 2005.

BPS Kota Bandung. (2005). Tabel Input Output Kota Bandung Tahun 2003. BPS Kota Bandung. BPS Kota Bandung. (2010). Tabel Input Output Kota Bandung Tahun 2008. BPS Kota Bandung. Nazara, Suahasil (2005). Analisis Input-Output. Edisi Kedua. LP-FEUI. Jakarta 


\section{Teti Sofia Yanti, Siti Sunendiari}

Rasyid, M. Ryaas (1997). Pembangunan Pemerintahan Indonesia Memasuki Abad 21'PT. Yarsif Watampone. Diunduh melalui URGENSI DAN MANFAAT ANALISIS POTENSI WILAYAH ... www.academia.edu/.../URGENSI_DAN...Academia.edu. Tanggal 8 Maret 2015 pukul 10.00.

Ronald E, Miller and Peter D. Blair, Input-Output Analysis, Prentice-Hall, Inc. Englewood Cliffs, New Jersey. 1985

RPJMD kota bandung 2014 - 2018 - Pemerintah Kota ... Diunduh melalui bandung.go.id/site/RPJMD.../Rancangan_Akhir_RPJMD_2014_02_16.p...Feb 16, 2014 - Bandung. Penyusunan RPJMD Kota Bandung Tahun 2014-2018 didasarkan ...... Tabel 2-5. Temperatur Rata-rata di Kota Bandung Tahun 2007-2011 . ... Pertumbuhan Kontribusi Sektor dan PDRB Kota Bandung Atas Dasar. Tanggal 8 Maret 2015 pukul 10.00. 